\title{
THE EFFECT OF PEER COACHING AS HEALTH COACHING SUPPORT ON PARENTING SELF EFFICACY TO INFANT CARE IN EARLY MARRIAGE MOTHER IN THE WAIPARE PUBLIC HEALTH CENTER WORKING AREA \\ Authors:
}

\author{
Yosefina Nelista ${ }^{1 *}$, Pembronia Nona Fembi $^{2}$ \\ ${ }^{1,2}$ Universitas Nusa Nipa \\ Email*: nelistayosefina@gmail.com
}

\begin{abstract}
Introduction: Early marriage is a practice that is still common in several countries in the world. Getting married at early age will have an impact on childcare. Marriage at an early age needs to obtain knowledge about childcare. Interventions provided to mothers who marry at early age to change her behavior is health coaching support. The purpose of the study was to analyze the effect of health coaching support by peer coaching method on parenting self-efficacy to infant care in mothers who married at early age. Methods: This study used a quasi-experimental design with one group pre-test and post-test design. The study population was early marriage mothers who had infant. We used purposive sampling technique with a sample of 15 participants. The instrument used in this study was the Maternal Self-Efficacy Scale. Results: The results showed that of the 15 participants, the mean pre-test and mean post-test were 1.73 and 3.46. Wilcoxon test results showed before and after being given health coaching support by peer with $p$-value $0,000<\alpha=0.05$, so Ho was rejected and Ha was accepted. This showed that there was a significant influence due to the provision of health coaching support by peer coaching methods on infant care. Conclussions: There was an increase in parenting selfefficacy on infant care in mothers who married at early age. It is expected that parents who married at early age could change their behavior and have confidence in parenting.
\end{abstract}

Keywords: health coaching, parenting self efficacy, baby care, early age.

\section{INTRODUCTION}

Marriage is a social bond that unites two people in one form of special dependence with the aim of forming and maintaining family integrity (Biresaw, 2014). Marriage can occur at the age of a child or teenager, which is referred to as early marriage. Early marriage according to the United Nations Children's Fund is a marriage before 18-year-old, both formal and informal (informal unions) (UNICEF, 2014).Early marriage is also called the term child marriage or teenage marriage (Kole\&Anuchitra, 2014; UNFPA， 2006; UNICEF, 2014). The ideal age for marriage according to the National Family Planning Coordinating Board (BKKBN) is between the ages of 20-24 years for women, and a minimum of 25 years for men, but there are still many people who are married before that age (BKKBN, 2015).

Early marriage is a practice that is still common in some countries in the world. Data from UNICEF shows that more than 700 million women ( 1 in 3 women) in the world are married at the age of children or adolescents (UNICEF, 2014). Research conducted in The Iraqi state, shows thatthe prevalence of early marriage is $15.7 \%$, where the number is almost evenly distributed among Muslims and Christians(Al-Ridwany\& AlJawadi, 2014). Whereas in Malawi, the prevalence of early marriage is very high, especially in women, which is $59.9 \%$ compared to male (13.7\%)(Adebowale\& Martins, 2013).

Indonesia is one of the countries with the highest percentage of young marriages in the world (ranked 37) and the second highest in the Association of Southeast Asian Nations (ASEAN) after Cambodia (BKKBN, 2012). In 2002 , the proportion of women married under the age of 15 in Indonesia was $2.8 \%$. This number decreased slightly in 2013, where among women aged 10-54 years, $2.6 \%$ were 
first married at the age of less than 15 years. While the number of women who married at the age 15-19 years old are 23.9\% (Ministry of Health, 2013). The 2013 Basic Health Research (Riskesdas), conducted by the Ministry of Health of the Republic of Indonesia revealed that among women 10-54 years, $2.6 \%$ were first married at the age of less than 15 years and $23.9 \%$ were married at the age of 15-19 years. This means that around $26 \%$ of underage women are married before the functions of their reproductive organs develop optimally.

Data from the Family Planning, Women's and Child Empowerment Control Office (P2KBP3A) of Sikka District, noted that in 2016 the number of pregnant women under the age of 20 in Sikka District were 558 people, meanwhile decrease into 400 people in 2017. Many who are married under age are caused by free association which causes pregnancy while at school. The Puskesmas with the highest number of pregnancies of children under age is at WaiparePublic Health Center, which is 25 people.Thenumber of underage pregnancies affects the addition of maternal and infant deaths. In 2016, the Infant Mortality Rate was 13 cases out of 251 births, while the Maternal Mortality Rate was 16 cases out of 88 birth processes.

Women who marry young tend to leave formal education and more quickly get pregnant (BKKBN, 2012; UNICEF, 2014). Maternal mortality in women aged 15-19 years is quite high, namely 70,000 deaths per year worldwide. While babies born to mothers less than 18 years of age also have a risk of death in their first year of $60 \%$ greater than babies born to mothers over 19 years of age. If the infants is able to survive,they also tend to suffer from low birth weight infants, low nutrition, and physical developmental delay (UNICEF, 2014).

For young women who have married early, psychologically and knowledge are still experiencing problems. Research conducted by Sabi (2012) in Maluku concluded that psychologically married teenage girls experience psychological distress, inability to coping mechanisms, inability to care for children and low self-esteem. Meanwhile, research conducted by Gyesaw\&Ankomah (2013) regarding the experience of pregnancy and childbirth in adolescent women in Ghana concluded that although pregnancy in adolescents is generally accepted, education is needed about parenting techniques that should be taught in sexual education program so they are ready to be mothers. Getting married at an early age will also have an impact on childcare. Therefore, new parents especially those who marry at an early age need to get knowledge about childcare so that when they have the confidence to be able to care for children (parenting self efficacy). One form of intervention or model that can be given to parents who get married at an early age to change behavior is health coaching support.

Health coaching is a method of guiding individuals to find ambivalence possessed by individuals to change health behavior.Health coaching effectively motivates behavior change through partnership, structurally supports between participants and trainers (Duke University Center ForIntergrative Medicine, 2006). Numerous studies show that health development (health coaching), effectively improve the health status or change the behavior of the patient (Dennis S., et al, 2013). According to the 2010 National Implementation Research Network (NIRN), health coaching with the peer couching repeat method or collegial process method in which the two groups work together to increase independence. This health development can be carried out by health professionals such as nurses.

Based on the results of literature studies and observations of existing phenomena, it was found that there was very little research on health couching support for parenting self efficacy in mothers who married at an early age, therefore it was necessary to conduct research. The purpose of this study was analyzing the Effect of Health Coaching Support on Peer Coaching Methods on 
Parenting Self Efficacy AboutInfant Care in Early Mothers in the WaiparePublic Health Center.

\section{METHOD}

This study was a quantitative research using a quasi-experimental design with one group pre-test and post-test design. The design of this study in one group without comparison. The effectiveness of the treatment was assessed by comparing the pretest and post-test score.

The population in this study were women or mothers who at the time of the study aged 15-20 years old with age at marriage $\leq 18$ years old and had infant as many as 20 participants.

The sampling technique used in this study uses purposive sampling. Purposive sampling is a sampling technique that is based on a particular consideration made by the researcher himself, based on the characteristics or characteristics of the population that has been known beforehand (Notoadmodjo, 2010). The reason for using this method is based on determining the desired sample must match the specified criteria. This criterion is in the form of inclusion and exclusion.

The inclusion criteria in this study were mothers who agreed to be respondents, aged 15-20 years old, married status and first marriage at age $\leq 18$ years old, having children aged 0-11 months, available to follow the research process until the end never received a health education regarding the infant care, whichwas known from the respondent's screening sheet.

Exclusion criteria in this study was had mental or physical disorders, had infant who had a mental or physical disorder, which was known from the baby's health record in integrated service post (posyandu) control book in each midwife.In this study health coaching support was provided for a span of 2 weeks, the establishmentof 4 stages coversthe assessment of readiness, education and motivation about infant care, training baby care techniquesand motivation and evaluatingand providing repetitive motivation. The independent variable in this study is health coaching support for the peer coaching method and the dependent variable is parenting self efficacy. The instrument used in this study was the Maternal Self-Efficacy Scale compiled by Teti\&Gelfand (1991).This questionnaire consists of 10 question items in 4 Likert scales. Data were analyzed using Wilcoxon test. Wilcoxon non-parametric test was used to determine differences in mean parenting self efficacy values before and after the provision of health coaching support.

This research was approved by the Ethics Commission for Health Research, Faculty of Health Sciences, NusaNipa University No: 288 / EC / FIKES / NN / VI / 2018.

\section{RESULTS}

Table1 Distribution of mothers based on age, age at marriage and education $(\mathrm{n}=15)$

\begin{tabular}{|c|c|c|c|}
\hline \multicolumn{4}{|c|}{ MaternalCharacteristics } \\
\hline No & $\begin{array}{c}\text { Mother's age } \\
\text { (years) }\end{array}$ & $\mathrm{f}$ & $\%$ \\
\hline 1 & 15 & 3 & 20 \\
\hline 2 & 16 & 2 & 13.3 \\
\hline 3 & 17 & 3 & 20 \\
\hline 4 & 18 & 5 & 33.3 \\
\hline 5 & 19 & 1 & 6.7 \\
\hline 6 & 20 & 1 & 6.7 \\
\hline \multicolumn{4}{|c|}{ Mother's age at marriage } \\
\hline 1 & 15 & 3 & 20 \\
\hline 2 & 16 & 9 & 60 \\
\hline 3 & 17 & 1 & 6.7 \\
\hline 4 & 18 & 2 & 13.3 \\
\hline \multicolumn{4}{|c|}{ Mother education } \\
\hline 1 & $\begin{array}{l}\text { Elementary } \\
\text { school }\end{array}$ & 5 & 33.3 \\
\hline 2 & $\begin{array}{l}\text { Junior high } \\
\text { school }\end{array}$ & 7 & 46.7 \\
\hline
\end{tabular}




\begin{tabular}{llll}
3 & $\begin{array}{l}\text { Senior } \\
\text { HighSchool }\end{array}$ & 3 & 20 \\
\hline
\end{tabular}

Based on table 1 above, it can be concluded that the highest maternal age is 18 years, that is 5 people $(33.3 \%)$ and those who are at least 19 years and 20 years old, namely 1 person $(6.7 \%)$. The mother's age at marriage is at most 16 years, which is 9 people $(60 \%)$ and at least 17 years old, that is 1 person $(6.7 \%)$.In terms of maternal education, the highest number of junior high school education is 7 people $(46.7 \%)$ and the least Senior HighSchooleducation is 3 people (20\%).

Table2 Distribution of infants based on age and order of infants $(n=15)$

\begin{tabular}{lccc}
\hline \multicolumn{3}{l}{ Characteristics of Infants } \\
\hline No & $\begin{array}{c}\text { Age of Infants } \\
\text { (month) }\end{array}$ & $\mathrm{f}$ & $\%$ \\
\hline 1 & 1 & 4 & 26.7 \\
2 & 2 & 4 & 26.7 \\
3 & 3 & 3 & 20 \\
4 & 4 & 2 & 13.3 \\
5 & 5 & 2 & 13.3 \\
Level ofInfants & & \\
1 & First & 13 & 86.7 \\
2 & Second & 2 & 13.3 \\
\hline
\end{tabular}

Based on table 2 it can be concluded that the age of infants is at most 1 year and 2 years old, each of them is 4 people $(26.7 \%)$ and those who are at least 4 and 5 years old are 2 people each (13.3\%). Viewed from the order of children, the first number of children is 13 $(86.7 \%)$ and the second child is at least 2 (13.3\%).

Table3 Statistical results of differences in average infant care before and after the provision of health coaching support on infant care with Shapiro-Wilk $(\mathrm{n}=15)$.

\begin{tabular}{lcc}
\hline $\begin{array}{l}\text { Parenting Self } \\
\text { Efficacy }\end{array}$ & Mean \pm SD & $p$ value \\
\hline $\begin{array}{l}\text { Pre test } \\
\text { Post test }\end{array}$ & $1.73 \pm 0.45$ & 0.000 \\
\hline
\end{tabular}

Z count: 3.508

Z table: 1.96

Based on table 3 above, it can be seen that the mean pretest parenting self efficacy about baby care for mothers who married early age before being given health coaching support is the peer coaching method is 1.73 while the mean value of posttest parenting self efficacy about baby care for mothers who marry early after being given health coaching support is 3.46. Judging from the $\mathrm{Z}$ value, the calculated $\mathrm{Z}$ value is 3.508 .

The value of $\mathrm{Z}$ table for samples less than 1000 is 1.96. Because the value of $Z$ count> $\mathrm{Z}$ table then $\mathrm{Ho}$ is rejected by $\mathrm{Ha}$ accepted. So it can be concluded that there is significant influence as a result of health coaching support method of peer coaching on parenting self-efficacy about infant care in women who married early age. Based on the results of Wilcoxon's test showed that before and after being given health coaching support the peer coaching method obtained p-value $0.000<\alpha=0.05$, thenHo is rejectedHa accepted. This shows that there is significant influence as a result of health coaching support peer coaching methods of infant care in women who married early age.

\section{DISCUSSIONS}

Health coaching is the practice of health education and health promotion with a view to improving individual health and to facilitate the achievement of health goals that effectively motivate behavioral change in a structured manner, through supportive relationships between participants and coaches (Huffman, 2007 in Effendy, 2016). Macadam (2014) mentions that the focus of health coaching includes factors that influence motivation, overcome barriers, overcome a patient's inability, influence patients not to limit themselves, produce solutions (alone / realistic), take small steps, review, reflection, support, build trust and self-confidence (self- 
acceptance, self-efficacy) and how to be more involved and make decisions.

The results showed that there was an effect of health coaching on peer coaching methods on parenting self efficacy (PSE) for infant care for mothers who married early agein the WaiparePublic Health Center work area. Based on the mean value of the pre test and post test, there was a significant increaseafter being given a health coaching method of peer coaching. The mean value of pretest parenting self efficacy about baby care for mothers who married early ages before being given health coaching support the peer coaching method is 1.73 , while the mean value of posttest parenting self efficacy about infant care in mothers who married early age after being given health coaching support was 3.46.

Health coaching on infant care includes a series of teaching and support programs that focus on knowledge, skills, feelings and tasks as parents (Einzig, 1996 cit. Bornstein et al., 2012). Health education with the peer coaching method approach has a positive effect on increasing PSE in mothers. Statistically there was a significant effect on increasing the mean PSE before and after being given health coaching with a mean difference of 1.73 and $p<0.00$. This may imply that health coaching support with peer coaching approach is effective in improving PSE mother married an early age.

This is in line with research conducted by M. Kartini, et al (2016) on the effect of health education on child care on parenting self-efficacy, knowledge and attitudes regarding child care in mothers who married an early age. The results showed that health education with an individual approach and lecture method and discussion were more effective in increasing the PSE of mothers who married early age.

Health coaching is one of the practices of health education which includes four stages, namely readiness assessment, providing education and motivation, training in prevention and transmission of motivation and evaluation and providing repeated motivation.
This is done trying to help individuals express what they want to achieve, what is disturbing, what they want to change, what support they need, help make changes and difficulties that need to be addressed or minimizedso as to overcome the health problems facing (National Health Service, 2014).

In this study health coaching support was provided for a span of 2 weeks and was effective in improving PSE. The two-week selection is based on previous research conducted by Bloomfield \& Kendall (2005) which measures PSE before and after the parenting program. This period of time is needed for the process of adopting behavior, as a result of health care provided. Theory changes according to Roger \&Shoamaker (1971 cit. Alhamda, 2015) states that to achieve appropriate or adapted behavior five steps are needed, namely self-awareness, interest, evaluation, trial and adoption. So that within two weeks between the completion of health training and the post-test implementation, respondents will begin to try what has been learned so that they can be more confident and confident to be able to carry out child care properly.

The success of health coaching support, among others, is determined by the method used. In this study health coaching was used in contrast to previous studies using the peer couching method. The peer couching method is an approach that involves 2 or more people who can work together to reflect the teaching practices being carried out, expand, improveand build new skills. The peer couching method in this study aims to enable mothers who get married at an early age to gather and share experiences. With this approach, mothers are expected to learn better because the information conveyed and received is adjusted to the problems faced by each mother.Every problem faced by the mother can be explored and assisted with the solution. Finally, the mother will voluntarily, based on awareness and understanding will change behavior (Notoatmodjo, 2005). 
One of the advantages of health coaching with the peer couching approach in this study is that it can have a positive effect on the mother,help mothers grow and enhance the sense of responsibility for every behavior and action taken,and encourage the mobilization of the best abilities through limitations that have been assumed by themselves.

Health coaching support with the peer coaching method can also increase maternal confidence. This is consistent with the opinion of Ghufron (2010)which states that the occurrence of new understandings can foster self-confidence or feel themselves capable and encouraging in determining choices to act.So it can be concluded that understanding that arises from health education regarding child care fosters the mother's confidence in caring for or caring for her child. Confidence in caring for children is also called parenting self-efficacy (Young, 2011; Winteret al., 2012).

Parenting self-efficacy (PSE) is an individual belief about their competence as parents, their ability to positively influence their children's behavior and development (Coleman\&Karraker, 2000 cit. UmanaTaylor,Guimond, Updegraff, \&Jahromi, 2013). Maternal PSE is very important for a woman's adaptation to becoming a mother. PSE is important to learn because of its relevance to parenting competencies (Umana-Taylor et al., 2013) and its relationship to positive childcare practices (Hill\&Bush, 2001 cit. Small, 2010). Parents who have low PSE will experience difficulties in applying knowledge about child care, experiencing emotional problems and focusing more on themselves than their children's needs (Grusecet al.,1994 cit. Small, 2010).There is some limitation should acknowledge in this study. First, we conducted a queasy experimental without control group which not counted the true effect of the program. Second, the sample size was smaller that would resultin less sensitivity to detect power or magnitude for the effect of the program. Third, we select a sample using convenience sampling that would introduce selection bias.

\section{CONCLUSIONS}

Health coaching support peer coaching methods canimprove parenting selfefficacy (PSE) of infant care in women who married early age in Waipare public health center. For this reason, it is expected that new parents, especially those who marry at early age, can change their behavior and have the confidence to be able to care for children (parenting self-efficacy).

\section{REFERENCES}

Adebowale, A. S., \& Martins, E. P. (2013). Cox-proportional Hazard Model of Gender Differentials in Determinants of Early Marriage: Evidence from 2010 Malawi Demographic Health and Survey. Gender \&Behaviour, 11 (2), 5421- 5438.

Al-ridhwany, H. H., \& Al-jawadi, A. A. (2014). Early Child Marriage in Mosul at North of Iraq: Prevalence and Preference. Middle East Journal of FamilyMedicine, 12(2).

BKKBN.

KajianPernikahanDinipadaBeberapaP rovinsi di Indonesia: Dampak Overpopulation, AkarMasalahdanPeranKelembagaan di Daerah.Retrieved from www.bkkbn.go.id.

BKKBN.(2015). Remaja Genre danPerkawinanDini-Policy Brief.

Retrieved from www.bkkbn.go.id

Coleman, P. K. \&Karraker, K. H. (2000), Parenting self-efficacy among mothers of school-age children: Conceptualization, measurement, and correlates, Family Relations, 49, 1, 1324

Coleman, P. K., \&Karraker, K. H. (2003).Maternal self-efficacy beliefs, competence in parenting, and toddlers' behavior and developmental status.Infant Mental Health Journal, 
24(2),

$126-148$. doi:10.1002/imhj. 10048

Dharma

MetodologiPenelitiankeperawatan.Jakar ta :CV. Trans Info Media.

Dennis, S. M.,Harris, M., Lloyd, J., Powell Davies, G., Faruqi, N.\&Zwar, N. (2013). Do people with existing chronic conditions, benefit from telephone coaching? A rapid review.Australian Hospital Association, 37(3), 381-8.doi: 10.1071/AH13005.

Gyesaw, N. Y. K., \&Ankomah, A. (2013). Experiences of pregnancy and motherhood among teenage mothers in a suburb of Accra, Ghana: a qualitative study. International Journal of Women's Health, 5, 773-780.

Huffman Melinda RN,. (2007). Health Coaching : A New and Exciting Technique to Enhance Patient SelfManagement and Improve Outcomes. Diaksestanggal 30 Febuari 2018 jam 19.30 WITA dari www.Wholehealtheducation.com/news/ pdf.s/health coaching.for health care provider.pdf.

Kemenkes RI. (2013). RisetKesehatanDasar; RISKESDAS (2013). Jakarta: BalitbangKemenkes RI. Retrieved from http://depkes.go.id/downloads/riskesdas 2013/Hasil Riskesdas2013.pdf

Marimbi, H. (2010). TumbuhKembang, Status Gizi, danImunisasiDasarpadaBalita. (W. Kristiyanasari, Ed.). Yogyakarta: NuhaMedika.

Notoatmodjo, S.

2010. Metodologipenelitiankesehatan. Jakarta: PT RinekaCipta.
Palmer, S.,Tubss, I., \&Whybrow,A. (2003).Health Coaching to facilitate the promotion of healthy behavior and achievement of health related goals. International Journal of Health Promotion and Education.

Rijen, E. H. M. Van, Gasanova, N., Boonstra, A. M., \&Huijding, J. (2013). Psychometric Qualities of the Short Form of the Self-efficacy for Parenting Tasks Index-Toddler Scale.Child Psychiatry \& Human Development, 45(4).

Salonen, A. H., Kaunonen, M., Åstedt-Kurki, P., Järvenpää, A. L., Isoaho, H., \&Tarkka, M. T. (2009).Parenting selfefficacy after childbirth.JournalofAdvanced Nursing, 65, 2324-2336. doi:10.1111/j.13652648.2009.05113.x

Small, R. P. (2010).A comparison of parental self-efficacy, parenting satisfaction, and other factors between single mothers with and without children with developmental disabilities.Wayne State University (Dissertation). Wayne State University.

The National Implementation Research Network (NIRN). (2010). Basic of Coaching a Brief Review Of Recent Literature.Noetheast and Cabbean Implementation Center.

UNICEF.(2014). Child Marriage.UNICEF. Retrieved from http://www.unicef.org/protection/57929 _58008.html

Unicef, \& World Health Organization. (2012). Care for Child Development: Participant Manual. Geneva: World Health Organization. 